\title{
Analisis Salasilah Tarekat Shaykh Shams al-Din al-Sumatra'i
}

\author{
An Analysis on Spiritual Chain of Shaykh Shams al-Din al-Sumatra'i \\ ROHAIMI RASTAM*, MOHD SYUKRI YEOH ABDULLAH \& YUSRI MOHAMAD RAMLI ${ }^{1}$
}

\begin{abstract}
This article examines the spiritual chain (silsilah tariqah) of Shaykh Shams al-Din al-Sumatra'i (alt. al-Sumatrani), Qadi al-Malik al-'Adil (Prime Minister and Mufti) of Aceh during the reign of Sultan Iskandar Muda in 1607 to 1627. The study is primarily based on his manuscript of Mir'at al-Muhaqqiqin as well as Shaykh Abdul Haqq Muhaddith Dahlawi's Zad al-Muttaqin. By mapping the lineage of all data available, this study features al-Sumatra'is spiritual chain that consist of Qadiriyyah, Shadhiliyyah, Madyaniyyah, Chishtiyyah and Shattariyyah orders.
\end{abstract}

Keywords: Aceh, al-Sumatra'i, al-Sumatrani, silsilah, spiritual chain, tariqah

Salasilah (silsilah) dan ijazah adalah perkara yang sangat penting dalam disiplin ilmu tarekat rohani. Murshid yang berperanan sebagai pemandu dan pemberi petunjuk mesti mempunyai silsilah dan ijazah sebagai tanda pengiktirafan daripada guru beliau. Seorang murshid yang asalnya salik dibaiat agar memiliki silsilah yang bersambung tali temali (tasalsul) sehingga sampai kepada Baginda Rasulullah (s.a.w.) Dia hanya dilantik sebagai murshid setelah diijazah dan diberi keizinan oleh shaykhnya untuk memimpin salik dengan pentarbiahan dan cara hidup ahlillah. Hanya yang telah belajar berhak mengajar, sebagaimana kalam hikmah Shaykh Abu Madyan: "Sesiapa yang menemui makhluk, sedangkan wujud hakikat belum menyerunya kepada Khalik (Maha Pencipta), maka ia tercela" (Ahmad ibn Ibrahim 2011). Ia bermaksud bahawa sesiapa yang memberikan pengajaran kepada orang lain sementara ia sendiri belum mencapai maqam membimbing dan menyempurnakan, belum menempuh aneka maqam ahli suluk dengan benar, belum menyerap semangat kalangan yang sudah sampai, serta wujud hakikat belum menyeru dan mengajaknya kepada al-Khaliq, maka ia tercela baik dalam kalangan awam mahupun kalangan khusus. Ia tercela kerana tidak memiliki izin daripada Tuhan, Pencipta manusia, untuk membimbing dan menunjukkan jalan bagi manusia menuju kepada-Nya. Sesiapa yang mendakwa dengan sesuatu ilmu sedangkan ia tidak disahkan oleh ahli dalam bidang berkenaan tentang sesuatu ilmu yang didakwanya, maka dia tidak layak untuk menerajui dalam bidang berkenaan. Hal ini kerana ijazah adalah bukti atau pengiktirafan atas kemampuan seseorang dalam bidang tertentu dan penanda aras bahawa ia telah mencapai suatu tahap kekukuhan yang diperlukan ('Abd al-Qadir Isa 2001).

\footnotetext{
1 Rohaimi Rastam*(Corresponding author), Ph.D. candidate at Institute of the Malay World and Civilization, Universiti Kebangsaan Malaysia, 43600 BANGI, Selangor, Malaysia, email: nurijannah@yahoo.com; Mohd Syukri Yeoh Abdullah, Ph.D., Assoc. Professor and Head of Malay Manuscript Research Centre at Institute of the Malay World and Civilization, Universiti Kebangsaan Malaysia, 43600 BANGI, Selangor, Malaysia, email: syukri@ukm.edu.my; Yusri Mohamad Ramli, Ph.D. candidate at Institute of the Malay World and Civilization and lecturer at Dept. of Theology and Philosophy, Faculty of Islamic Studies, Universiti Kebangsaan Malaysia, 43600 BANGI, Selangor, Malaysia, email: yusri_mr@ukm.edu.my.
} 
Shaykh Ibn Athaillah al-Sakandari ketika menjelaskan mengenai keutamaan dan sejarah hidup gurunya Shaykh Abu al-Abbas Mursi lebih dahulu mengawalinya dengan penjelasan tentang Shaykh Abu al-Hassan al-Shadhili (alt. al-Shadhuli/al-Shadhali), iaitu Shaykh kepada guru beliau. Tujuan kenapa beliau berbuat sedemikian ialah untuk menunjukkan kedudukan dan kemuliaan Shaykh Abu al-Abbas kerana kemuliaan seseorang bergantung kepada siapa yang menjadi ikutan atau gurunya. Maka pentingnya kejelasan silsilah adalah kerana silsilah mengisyaratkan rantaian pembimbing. Silsilah dinisbah kepada insan yang memikul tanggungjawab membimbing sambung menyambung dan bukannya semudah dinisbah kepada Timur atau Barat seperti mana yang dinyata oleh Shaykh Abu al-Abbas Mursi: "Tarekat kami ini tidak bernisbah ke Timur atau ke Barat, namun dinisbahkan dari seseorang ke seseorang yang lainnya hingga sampai kepada al-Hassan ibn Abi Thalib (r.a.) (w. 670M). Dia adalah wali kutub pertama"(Abd al-Halim Mahmud 1119H). Seorang salik mesti menetapkan dengan jelas siapa Shaykh atau gurunya yang ia jadikan sandaran menuju Allah. Jika tidak, kebenaran tarekat (perjalanan rohani) dan pencapaian makrifahnya diragukan. Hal demikian kerana tarekat adalah riwayat, dan riwayat harus jelas siapakah rujukannya, kerana ia adalah pemandu yang memberi petunjuk sepanjang perjalanan hidupnya. Allah mampu untuk 'menarik' seorang hamba kepada-Nya tanpa melalui guru, atau seseorang langsung bertemu Rasulullah (s.a.w.) yang memberinya pengetahuan. Namun begitu, pertemuan dengan Rasulullah (s.a.w.) adalah rahsia daripada orang ramai tentang kedudukan yang maqamat dan ahwalnya yang perlu ditashih oleh Shaykhnya bahawa yang ditemuinya itu adalah benar-benar Baginda Rasulullah (s.a.w.). Pertemuan itu adalah rahsia kecuali Shaykhnya kerana ia akan jadi fitnah riyak yang akan binasa salik tersebut. Perkara seumpama itu boleh menjadi kurnia dan juga boleh menjadi hijab baginya jika tidak memposisinya dengan betul (Abd al-Halim Mahmud 1119H).

Shaykh Abdul Qadir Isa (2001) menjelaskan bahawa tidak harus seseorang mendakwa sebagai murshid tanpa ijazah rasmi untuk memberi bimbingan (irshad) daripada murshid yang berkelayakan dan bersambung silsilah mereka kepada Rasulullah (s.a.w.) sebanding ulama hadith yang memindah hadith Rasulullah (s.a.w.) dengan silsilahnya dari seorang perawi ke seorang perawi sehingga kepada Rasulullah (s.a.w.). Kerana itulah Ibn al-Mubarak berkata: "Sanad itu sebahagian daripada agama, tanpa sanad nescaya manusia bebas berkata apa sahaja yang diingini". Sesiapa yang mempelajari maqam ilmu zaman lampau, pasti mengetahui betapa bernilainya memiliki ijazah daripada Shaykh dan betapa pentingnya mempelajari ilmu secara talaqqi (bersemuka) daripada mereka sehingga mereka mengaitkan orang yang tidak mengambil ilmu daripada ulama sebagai al-Suhufi kerana mengambil ilmu semata-mata daripada helaian-helaian kertas serta pembacaan sendiri. Nukilan Shaykh Abdul Qadir Isa (2001) daripada Ibn Sirin (r.a.) (w. 728M) menyatakan: "Sesungguhnya ilmu ini adalah agama, maka perhatikanlah secara berhati-hati daripada siapa kamu mengambil agamamu".

Pengijazahan daripada Shaykh membuktikan bahawa seseorang itu telah sempurna melalui pentarbiahan dan telah mencapai tahap yang ditentukan sehingga layak menerajui bidangnya, kerana telah melalui pengalaman langsung, iaitu keadaan yang dirasainya (arbab alahwal) dan bukan diperoleh daripada pengertian takrif yang boleh disusun dan dituturkan dengan perkataan (arbab al-aqwal) melalui tarekat rohani. Amat jauh bezanya antara orang yang mengetahui takrif mabuk dengan orang yang sedang mabuk yang tidak tahu takrif mabuk, malah tidak tahu dirinya mabuk sama sekali. Doktor perubatan yang sedang sakit tahu tentang apa takrif sihat, punca penyakit dan cara pengubatannya supaya menjadikan seseorang pesakit itu sihat (Al-Ghazali 1988). Begitulah perbezaan antara orang yang mengenal hakikat dengan orang yang mengalami dan merasai pengalaman hakikat. Amat tidak patut seseorang itu merasa cenderung untuk mengubati jiwanya dengan guru yang tidak berkelayakan. Begitulah juga sebaliknya, amat tidak patut seseorang yang tidak berkelayakan cenderung untuk mengubati jiwa seseorang yang sakit. 
Salik yang dibaiat oleh Shaykh dan akhirnya maju sehingga layak menjadi seorang khalifah tarekat akan menjadi pewaris yang menyambung silsilah. Hanya pewaris para Nabi, yang dibentuk oleh silsilah tarekat rohani, layak untuk memimpin salik menuju Allah. Para ahlillah bersetuju bahawa memasuki kehidupan yang hakikatnya adalah sebuah perjalanan tanpa bimbingan Shaykh adalah mustahil. Menurut Abu Yazid (r.a.), Shaykh Ahmad al-Qushashi (w. 1661M) (1909), Shaykh Abdul Rauf Singkil (MS1314 C) dan lainnya bahawa orang yang tidak memiliki Shaykh, maka gurunya adalah syaitan (Ahmad ibn Ibrahim 2011). Justeru silsilah melalui perawi yang thiqah (terpercaya) sampai kepada Rasulullah (s.a.w.) adalah salah satu daripada ciri pokok dalam displin-ilmu tarekat rohani. Baiat antara salik dengan Shaykh tarekat yang kebiasaannya berlaku dengan cara mentalqinkan kalimah La ilaha illa Allah akan memastikan berlakunya penurunan silsilah kepada salik bersambung dengan Shaykh yang membaiatnya sehingga sampai kepada Rasulullah (s.a.w.). Apabila kemudiaannya salik tadi maju dan layak dilantik sebagai khalifah tarekat sama ada melalui pengurniaan khirqah ataupun tidak, maka silsilah tersebut akan bersambung pula kepada murid bagi individu yang dilantik menjadi khalifah tarekat rohani tadi. Shaykh Ahmad al-Qushashi (1909) berkata:

Guru atau Shaykh yang mempunyai silsilah sanad sampai kepada Rasulullah (s.a.w.) adalah pemimpin mereka bagi pihak Rasulullah (s.a.w.). Oleh itu, sesiapa yang berbaiat dengan guru tersebut bermakna ia berbaiat dengan Rasulullah (s.a.w.) seperti yang diperjelaskan oleh kata-kata Sayyidina Umar bin al-Khattab kepada orang yang datang berjumpa dan berkata kepadanya: "Aku ingin berbaiat dengan Tuan!" Sayyidina Umar berkata: "Sudahkah kamu berbaiat dengan pemerintah aku?" "Ya," jawab orang itu. Sayyidina Umarpun berkata: "Jika kamu telah berbaiat dengan pemerintah aku bermakna kamu telah berbaiat dengan aku." Hal ini juga dibayangkan oleh jawapan kaum wanita Ansar kepada Sayyidina Umar bin al-Khattab, apabila beliau diutuskan oleh Rasulullah (s.a.w.) kepada mereka untuk membaiatkan mereka. Maka beliau (Sayyidina Umar) berkata: "Sesungguhnya aku utusan bagi pihak Rasulullah (s.a.w.)": jawab kaum wanita itu dengan penuh rasa gembira "Selamat datang wahai Rasulullah (s.a.w.) dan utusan Rasululah (s.a.w.)." Ucapan ini sejajar dengan terpancarnya sifat Baginda pada diri orang yang diutusnya dan keimanan mencapai maqam ihsan telah tersemat dalam hati mereka seolah-olah mereka melihat Baginda (s.a.w.).

Demikianlah silsilah akhirnya bertaut kepada Rasulullah (s.a.w.) kerana Baginda sumber segala dan asal pensaluran cahaya dan ilmu. Bersumber kepada telaga cahaya ilmu Baginda yang ummi (buta huruf) inilah, para ulama mengembang pelbagai ilmu menerusi pelbagai pendekatan penelitian, seperti tarekat, tafsir, qiraat, hadith, tauhid, fikah, tasawuf, falsafah, seni, kimia, perubatan, astronomi dan lain-lain. Dari sini muncul silsilah ilmu bertaut kepada ulama yang mengembang pelbagai ilmu dalam kehidupan manusia untuk mencapai ma'rifatullah, mardhatillah dan tawhidullah (Mohd Syukri Yeoh 2011).

\section{Baiat Dalam Disiplin Ilmu Tarekat Rohani}

Demi membolehkan silsilah diperturunkan kepada pewaris seterusnya, maka baiat antara guru dengan murid perlu dilakukan. Murid apabila memulakan perjalanan menuju ke jalan Allah, dia harus bermula dengan salah satu daripada dua cara sama ada dengan ta'alluq suwari atau dengan ta'alluq ma 'nawi. Maksud ta'alluq suwari ialah murid mengambil baiat atau talqin dari guru mursyid atau kedua-duanya sekali dan dia mematuhi wasiat gurunya tanpa melanggarinya sama ada dia menetap atau musafir. Perintah yang dipatuhi itu akan mengawalnya dan 
membawanya ke matlamat sekalipun ia berjauhan di mata, tetapi dia dekat di hati. Jika berlaku kepadanya sesuatu yang menghalangnya dari mentaati pesanan gurunya, ia akan jadikan pesanan gurunya itu sebagai wasilah untuk menghentikan perbuatan tersebut, tetapi bukan disebab halangan yang berterusan sebaliknya bolehlah pesanan itu diamal mengikut kemampuan. Walaupun begitu murid dinasihatkan untuk berusaha tanpa memberi alasan bagi memenuhi pesanan guru dan jika tidak berupaya, kembali kepada cara kebiasaannya dan ikutlah cara ahlillah sekadar kemampuannya (Al-Qushashi 1909).

Manakala ta'alluq ma`nawi ialah dia mengambil baiat dan talqin atau salah satu dengan berdamping dan berkhidmat untuk mencari makna demikian itu dan hasilnya sehingga layak menjadi pengganti hakiki. Jika dia sudah mencapai tahap kemampuan sebagai guru, maka layaklah baginya untuk berdiri sendiri. Ia seperti anak sebenar yang boleh mewarisi segala harta orang tuanya. Jika dia berkongsi dengan yang lain, maka hartanya itu dibahagikan mengikut pengalaman indera dan mengikut kesesuaian umur yang mana kecil dan yang mana besar dan juga mengikut keutamaan yakni diutamakan bagi yang lebih besar dan yang lebih muda menunggu. Maka sudah tentu dari kalangan mereka adalah yang terbaik oleh sebab pengalaman yang lebih lama dalam tarekat secara hissi (lahiriah) dan ma 'nawi. Jika terdapat waris lain yang lebih layak, bolehlah diganti sebagai guru setelah dikhalwahkan diberi baiat ijazah Shaykh. Kedudukan salik dalam ahli tarekat itu sama ada sebagai seorang yang baru atau yang sudah berpengalaman, suka serta mentaati perintah, menyerah diri sepenuhnya ataupun dengan ada kekurangan tetapi penyertaannya itu telah dianggap tergolong dalam ahli tarekat dan mencapai kemahuannya serta menjadi anak murid yang sah selagi ia tidak meninggalkannya dan berpaling daripadanya (Al-Qushashi 1909). Baiat bukan hanya sematamata menyambung silsilah sehingga sampai kepada Rasulullah (s.a.w.), tetapi juga mengandungi beberapa kelebihan. Antara contoh kelebihan mengambil zikir secara bersilsilah melalui baiat tarekat ialah didoakan oleh Shaykh agar Allah menghidupkan zikir di samping kelebihan lain yang dinyata oleh Allah khusus kepada Shaykh seperti yang disebut oleh Shaykh Ahmad al-Qushashi (1909) dalam kitab Simt al-Majid:

Dan ini adalah satu kedudukan tinggi baginya dalam sanad sehingga sampai ke tempat Shaykh Sayyiduna Muhammad Ghawth Allah dan melaluinya bersambung sanad kami ini kepadanya. Maka segala puji bagi Allah atas segala nikmat-Nya yang mulia yang telah menyambungkan susur galur sanad sampai kepada para khulafa al-Rashidin. Pujian bagi Allah atas kalimah-Nya yang sempurna, yang diminta perlindungan dengan-Nya daripada segala kesusahan yang zahir ataupun tersembunyi. Segala puji hanya bagi Allah yang tidak terkira, Dialah Penolong yang Terpuji. Semuga Allah redhai mereka semua. Dan semuga Allah menghidupkan zikir mereka yang berbaiat dengan kami dan yang menerima zikir secara lisan. Allahlah yang menghidupkan zikir mereka dan menzahirkan pujian untuk mereka. Segala puji dan syukur bagi Allah yang menjadikan mereka tidak mengindahkan dunia bahkan akhirat menjadi pilihan. Dan sesungguhnya didatangkan Allah kepada kami dalam mimpi yang baik pada beberapa tahun yang lalu bahawa sesiapa yang menerima zikir daripada kami secara lisan, Allah akan tetapkan imannya. Alhamduli'Llah. Sebelum penciptaan alam Ia telah dipuji oleh setiap lisan, disembah di setiap tempat. Oleh itu, kami berdoa kepada Allah dengan kemuliaan-Nya yang berterusan, dan kebaikannya sejak azali agar sesiapa yang menerima dari kami secara lisan memperoleh yang demikian sepanjang hayatnya, sesungguhnya Allah Maha Mulia, kemuliaan-Nya hanya diketahui oleh orang yang mulia. 


\section{Berbilang Tarekat Bagi Shaykh}

Menggunakan pelbagai aliran tarbiyah ruhiyyah tarekat rohani bukanlah satu perkara yang terlarang bagi seorang Shaykh dalam mendidik saliknya. Malah keupayaan ini menunjukkan pengiktirafan ke atas seorang Shaykh yang membolehkan beliau merangkum pelbagai kaedah tarbiyah al-Ruhiyyah daripada pelbagai aliran tarekat rohani. Shaykh Ali Muttaqi (w. 1567M) contohnya mewarisi empat aliran tarekat, iaitu Qadiriyyah, Shadhiliyyah, Madyaniyyah dan Chishtiyyah dengan bawaan tarbiyah al-Ruhiyyah tarekat induknya Qadiriyyah. Perkara ini bermakna Shaykh Ali Muttaqi pada kebiasaannya mengijazahkan tarekat Qadiriyyah kepada murid beliau atau sekiranya mahu boleh mengijazahkan mana-mana tiga aliran tarekat yang lain atau kesemuanya sekali berdasarkan kecenderungan murid yang diperhati oleh beliau. Dalam mendidik atau memberi latihan ke atas murid, Shaykh sebegini bebas memilih atau menyatukan kaedah daripada mana-mana tarekat yang diwarisinya. Namun apabila seseorang murid itu mencapai peringkat layak diiktiraf sebagai Shaykh, maka keseluruhan aliran tarekat gurunya akan diwarisinya. Hal inilah yang berlaku kepada Shaykh Abdul Wahhab Muttaqi (w. 1606M) murid kepada Shaykh Ali Muttaqi.

Selanjutnya terdapat penyatuan sekurang-kurang 30 aliran tarekat yang diwarisi oleh murshid tarekat Shattariyyah, al-Qutb al-Shaykh Ahmad al-Qushashi (1909) merangkumi tarekat Shattariyyah, Chishtiyyah, Firdawsiyyah, Kubrawiyyah, Suhrawardiyyah, Qadiriyyah, Tayfuriyyah, Akbariyyah, Uwaisiyyah, Shadhiliyyah, Uwaysiyyah, Khalwatiyyah, Hamadaniyyah, Naqshbandiyyah, Batiniyyah, Ghawtsiyyah Junaidiyyah, Bistamiyyah, Dasuqiyyah, Khaujakan, Ahmadiyyah Badawiyyah, Ahmadiyyah Shinawiyyah, Muhammadiyyah dan lain-lain lagi. Keizinan pengurniaan sanad kepada murid beliau dinyata setelah menyebut silsilah tarekat rohani berkenaan seperti yang berikut, katanya: "Sesungguhnya aku kurniakan ijazah sanad yang diambil daripada susur galur yang terdahulu dan kepada yang akan datang serta dinisbahkan kepada kami bagi yang mengambil daripada kami, khususnya anak didik kami, iaitu Ibrahim bin Hasan (w. 1689M)". Demikianlah pengunaan berbilang metode tarbiah al-Ruhiyyah tarekat rohani bagi seorang Shaykh bukanlah sesuatu yang asing dan rujukan mengenai perkara ini dapat ditemui dalam khazanah ilmu tarekat rohani seperti kitab Simt al-Majid (Kalung Kemuliaan) dan Zad al-Muttaqin (Peningkatan Orang Bertaqwa), seperti yang telah dinyatakan dan ini sekadar menyebut beberapa kitab.

\section{Silsilah dalam Manuskrip Mir'at al-Muhaqqiqin}

Melalui penelitian ke atas hasil penulisan Shaykh Shamsuddin al-Sumatera`i, tanpa ragu beliau adalah seorang yang bertaraf murshid tarekat rohani. Salah seorang di antara murid beliau ialah Sultan Iskandar Muda Meukuta Alam (1607-1636M), pemerintah Aceh Darussalam. Tentang Shaykh Shamsuddin sebagai seorang murshid tarekat, A. H. Johns (1997) mengemukakan pendapatnya:

The nisba al-Samatrani indicates that Shams al-Din was associated with Samatra/Samudra, a region in north Sumatra. Little is known of his early life, but from the first decade of the 17th century on, he played a prominent role at the court of Sultan Iskandar Muda (Makuta 'Alam 1607-36), most powerful of the Achehnese sultans, with the title Shaykh al-Islam, serving as leading authority in religious matters, as Sufi murshid to the sultan, whom he inducted into the Nakshbandiyya tarika, as his vicegerent on a number of occasions, and as his negotiator with foreign emissaries such as the Englishman Sir James Lancaster in 1602. 
Beliau turut mengemukakan: "He was particularly close to Sultan Iskandar Muda (r. 1607-36). There is evidence to suggest that Shams al-Din was the sultan's murshid (spiritual guide), and that he inducted him into a tariqah (Sufi order)" (Johns 2009); "Of the three sultans he served, he was closest to Iskandar Muda (r. 1607-36). He was the Sultan's murshid (mystical guide), and he inducted him into a tarekat (Sufi order)" (Johns 2009). Demikian Johns berpendapat bahawa Shaykh Shamsuddin al-Sumatera`i adalah seorang murshid tarekat Naqshbandiyyah. Namun begitu, Johns tidak mengemukakan sebarang bukti dakwaannya bahawa Shaykh Shamsuddin adalah murshid tarekat Naqshbandiyyah. Tetapi untuk berlaku adil kepadanya, Johns juga tidak menyatakan bahawa tiada bukti bertulis bagi menyokong dakwaannya. Sesuatu yang pasti dalam hal ini ialah Shaykh Shamsuddin al-Sumatera i adalah murshid tarekat, maka semestinya pasti memiliki silsilah tarekat yang bersambung sampai kepada Rasulullah (s.a.w.) kerana seseorang yang dilantik sebagai murshid tarekat rohani atau ingin berperanan sebagai pembimbing rohani, tidak dapat membimbing salik menuju Allah melainkan dengan pentauliahan sebagai Shaykh tarekat daripada gurunya. Justeru, usaha pencerahan silsilah tarekat Shaykh Shamsuddin al-Sumatera`i akan menatijahkan kepada pengenalpastian aliran tarekat rohani beliau, membawa kepada membuka lebih ruang kepada pengkajian lanjutan. Setakat ini satu-satunya silsilah yang diketahui ditulis oleh Shaykh Shamsuddin al-Sumatera i ialah silsilah ilmu makrifat Allah yang boleh ditemui dalam manuskrip Mir'at al-Muhaqqiqin.

Sangidu (2008) melalui tesis beliau Wahdatul-Wujud dalam Ma'ul-Hayat li Ahlil-Mamat: Analisis Resepsi terhadap Konsep Maujud dan Wujud Dalam Tibyan, Mir'atul Muhaqqiqin, Sharabul-cAshiqin, al-Muntahi, dan Suntingan Teks telah menemui silsilah ilmu makrifat Allah Shaykh Shamsuddin di dalam manuskrip Mir'at al-Muhaqqiqin koleksi Muzium Negeri Aceh. Namun, Mir'at al-Muhaqqiqin tidak diteliti dalam pengkajian sama ada oleh Van Nieuwenhuijze, Abd Aziz Dahlan, Mohd Nasrin (2008) mahupun Mohd Rushdan. Kitab ini disebut oleh Shaykh Nuruddin al-Raniri sebagai karya Shaykh Shamsuddin al-Sumatera`i di dalam Tibyan (Nuruddin al-Raniri 1955) dan Ma ul Hayati (Ahmad Daudy 1978). Manuskrip Mir'at al-Muhaqqiqin MS3841 (B) simpanan Perpustakaan Negara Malaysia mempunyai 24 halaman dengan halaman pertama terdiri daripada 10 baris, halaman berikutnya 19 baris dan halaman akhir 20 baris. Manuskrip kedua Inv. 1490 koleksi Muzium Negeri Aceh mempunyai 18 halaman (Sangidu 2008). Manuskrip ketiga 4208/07.1436 pula mempunyai 36 halaman dengan purata 11 baris setiap halaman, juga koleksi Muzium Negeri Aceh.

Manuskrip pertama MS3841 (B) dan kedua Inv. 1490 masing-masing mempunyai tiga bab, iaitu pertama Sejarah Ilmu Makrifat Allah, kedua Nisbah Makhluk dengan Haqq Taala dan ketiga Wujud Allah Dan Martabat Wujud-Nya. Manuskrip ketiga 4208/07.1436 hanya mempunyai dua bab, iaitu bersamaan dengan dua bab yang terakhir pada dua manuskrip yang dinyata sebelum ini. Judul dan nama pengarang jelas tercatat pada halaman pertama Mir'at alMuhaqqiqin Inv. 1490 dan Mir'at al-Muhaqqiqin 4208/07.1436 hanya tercatat judul tanpa nama pengarang. Manakala judul dan nama pengarang tidak dicatat pada manuskrip Ms3841 (B). Walaupun begitu disebabkan isi kandungan manuskrip Ms3841 (B) adalah bersamaan dengan manuskrip Inv. 1490 dan manuskrip 4208/07.1436 (walaupun manuskrip 4208/07.1436 hanya mempunyai dua bab tanpa bab pertama), maka atas persamaan itu kesemua manuskrip berkenaan adalah dikenalpasti sebagai manuskrip Mir'at al-Muhaqqiqin. Ungkapan halaman pertama Mir'at al-Muhaqqiqin (4208/07.1436) menyatakan judul manuskrip itu: "Kitab ini bernama Mir'at al-Muhaqqiqin ertinya cermin segala orang yang tahu pada ilmu tahqiq pada menyatakan nisbah ertinya bangsa". Bagi mengukuhkan lagi bahawa manuskrip ini adalah karangan Shaykh Shamsuddin al-Sumatera`i sekalipun nama beliau jelas tercatat pada 
manuskrip Inv. 1490, rujukan dibuat ke atas manuskrip $M a^{\prime}$ al-Hayah karangan Shaykh Nuruddin al-Raniri. Di dalam manuskrip Ma' al-Hayah (MS 547) ungkapan berikut ditemui:

Syahdan adalah beberapa lagi banyak iktikad kufur dan dhalalah itu tersebut di dalam kitab karangan Shamsuddin Sumatera`i seperti kitab Khirqah dan Mir`at al Muhaqqiqin dan Haqq al-Yaqin dan lagi pula beberapa kitabnya yang simpan, tiada terhisab dan di dalam karangan Hamzah Fansuri seperti kitab Muntaha.

Maka dari sisi kepengarangan dapat dikenalpasti bahawa Mir'at al-Muhaqqiqin adalah hasil tulisan Shaykh Shamsuddin al-Sumatera`i. Bab pertama kitab Mir'at al-Muhaqqiqin menjelaskan mengenai sejarah ilmu makrifat Allah disampaikan dalam bentuk silsilah. Ilmu makrifat Allah dikatakan diwarisi secara turun temurun oleh Shaykh Shamsuddin daripada rantaian guru beliau. Senarai Shaykh yang terdapat di dalam silsilah berkenaan dimulai daripada guru beliau sehingga kepada Rasulullah (s.a.w.) Selanjutnya bab kedua menjelaskan mengenai nisbah antara makhluk dengan Haqq Taala yang dipecahkan kepada nisbah fi'il (perbuatan), nisbah sifat (peri) serta nisbah zat dan wujud. Semua perbahasan menjurus kepada perbahasan hakikat. Seterusnya bab ketiga dimulai dengan dalil al-Quran dan perkataan arif yang salah seorang daripadanya ialah Shaykh Muhammad ibn Fadhlullah al-Burhanpuri. Menurut Shaykh Shamsuddin al-Sumatera i kesimpulan daripada perkataan Shaykh Muhammad Fadhlullah menjadikan ilmu makrifat Allah terbahagi kepada ma'rifah tanzih Haqq Taala dan ma'rifah tashbih Haqq Taala. Kitab diteruskan dengan penjelasan Martabat Tujuh. Sesudah dengan panjang lebar menjelaskan Martabat Tujuh dikemukakan dalil daripada al-Quran, hadis qudsi dan perkataan wali Allah mengenai keesaan wujud Allah. Kitab disudahi dengan selawat ke atas Nabi Muhammad (s.a.w.).

Shaykh Shamsuddin al-Sumatera i menyatakan mengenai silsilah beliau dalam Mir'at alMuhaqqiqin (Ms3841 [B]) simpanan Pusat Manuskrip Melayu, Perpustakaan Negara Malaysia, seperti berikut:

Bab yang pertama pada menyatakan peri sejarah ilmu makrifatullah. Ertinya turun temurun ilmu makrifatulLah itu pertama daripada Shaykh Muhammad ibn Jani Jamilah yang lagi dia beroleh ilmu makrifatullah yang sempurna daripada Shaykh Abdul Wahhab, yang lagi dia daripada Shaykh Ali Muttaqi yang lagi dia daripada Shaykh Muhammad Sakhawi, yang lagi dia daripada Shaykh Tahir Zawawi, yang lagi dia daripada Shaykh Ahmad Marzuq, yang lagi dia daripada Shaykh Ali ibn Umar, yang lagi dia daripada Shaykh Salih Zawawi, yang lagi dia daripada Shaykh Ahmad Hiti, yang lagi dia daripada Shaykh Sharifuddin Adli, yang lagi dia daripada Shaykh Ibrahim, yang lagi dia daripada Shaykh Muhyiddin Abdul Qadir Jilayni, yang lagi dia daripada, Shaykh Said bin Ali, yang lagi dia daripada Shaykh Abdul Rahman, yang lagi dia daripada Abdul Wahid bin Abdul Aziz, yang lagi dia daripada Shaykh Abdul Aziz Tamimi, yang lagi dia daripada Shaykh Ibn Bakar Sibli, yang lagi dia daripada Shaykh Junaid bin Muhammad, yang lagi dia daripada Sirr al-Saqati, yang lagi dia daripada Shaykh Maaruf alKharkhi, yang lagi dia daripada Sayyid Ali al-Redha, yang lagi dia daripada Sayyid Musa al-Kazim, yang lagi dia daripada Shaykh Jaafar Sadiq, yang lagi dia Zainal Abidin ibn Husin ibn Ali, yang lagi dia daripada Amirul Mukminin Ali ibn Thalib yang lagi dia daripada menengar ilmu makrifat Allah daripada hadrat Nabi Muhammad Rasulullah bermula ilmu makrifat Allah yang sempurna itu daripada Allah Subhanahu wa Taala seperti yang tersebut dalam kitab ini. Wallahu a'lam bissawab. 
Sungguhpun silsilah berkenaan dengan jelas dinyata sebagai silsilah ilmu makrifat Allah, silsilah ini dapat juga dikatakan sebagai silsilah tarekat atau dengan kata lain Shaykh Shamsuddin al-Sumatera i mengisyaratkan kepada silsilah tarekat dipandang dari sisi disiplin ilmu tarekat itu sebagai ilmu yang menyampaikan kepada hakikat dan seterusnya makrifat Allah. Lalu diutamakan oleh Shaykh Shamsuddin perkataan silsilah ilmu makrifat Allah sebagai matlamat bertarekat. Hal ini bersamaan dengan pernyataan yang dibuat oleh Shaykh Hamzah Fansuri, murshid tarekat Qadiriyyah ketika memperkenalkan guru utama silsilah tarekat beliau melalui rubacinya sambil merujuk pengijazahan khalifah tarekat sebagai satu ilmu yang bersifat tinggi. Shaykh Hamzah Fansuri melalui Ruba'i beliau mengisyaratkan tarekat rohani yang bersilsilah sebagai ilmu yang bersifat tinggi, iaitu membawa kepada makrifat Allah, dengan kata Shaykh yang dinukil (Drewes \& Brakel 1986):

Hamzah nin ilmunya zahir
Ustaznya Sayyid Abdul Qadir
Mahbubnya selalu hadir
Dengan dirinya nentiasa satir.

Hamzah nin asalnya Fansuri

Mendapat wujud di tanah Shahrnawi

Beroleh khilafat ilmu yang 'ali

Daripada Abdul Qadir Jilani.

Hubung kaitnya perkara ini kerana silsilah tarekat merangkumi silsilah ilmu dan silsilah amal. Silsilah ilmu meliputi silsilah pengajaran dan pengajian kitab, manakala silsilah amal sebagai contohnya ialah silsilah pengamalan hizib, selawat dan sebagainya. Ambil contoh murshid tarekat Shattariyyah Shaykh Ahmad al-Qushashi telah menerima secara lisan, bersalam, memakai khirqah, bersahabat dan mengambil sanad kitab al-Jawahir al-Khams Shaykh Sayyid Muhammad Khatiruddin Ghawth (w. 1562M) (1971) dan ilmu-ilmu, zahir dan batin daripada bapanya. Selanjutnya al-Qushashi (1909) menukilkan silsilah yang bersamaan dengan silsilah tarekat Shattariyyah.

\section{Silsilah dalam Manuskrip Zad al-Muttaqin}

Perbincangan setakat ini telah mengemukakan silsilah yang dinukil oleh Shaykh Shamsuddin alSumatera i dalam karangan beliau, iaitu silsilah yang dapat diteliti melalui manuskrip yang terdapat di Alam Melayu. Namun silsilah berkenaan tidak menjelaskan aliran tarekat rohani beliau. Sekiranya terdapat manuskrip yang lain sama ada di luar atau di Alam Melayu, maka satu perbandingan dapat dibuat. Persoalannya adakah silsilah seperti itu dapat dikesan tercatat dalam manuskrip selain Mir'at al-Muhaqqiqin? Sekiranya ditemui adakah dinyata aliran tarekat bagi silsilah berkenaan? Siapakah pengarang yang juga mewarisi silsilah yang sama seperti yang dinyata oleh Shaykh Shamsuddin al-Sumatera i dalam Mir'at al-Muhaqqiqin?

Kesemua persoalan ini dapat terjawab apabila meneliti manuskrip Zad al-Muttaqin Fi Suluk Tariq al-Yaqin karangan Shaykh Abdul Haqq Muhaddith Dahlawi (w. 1642M) (2009) murid kepada Shaykh Abdul Wahhab Muttaqi (943H/1536M-1015H/1606M). Pada asalnya manuskrip itu dalam bahasa Farsi. Zad al-Muttaqin mula ditulis pada tahun 1003H/1594 M. Pada ketika penulisan kitab berkenaan gurunya iaitu Shaykh Abdul Wahhab al-Muttaqi berusia 66 tahun dan telah menunaikan haji sebanyak 46 kali. Guru beliau pada ketika itu adalah penduduk tetap Mekah. Hal ini bermakna ketika penulisan kitab ini dimulakan oleh Shaykh 
Abdul Haqq di India, Shaykh Shamsuddin al-Sumatera`i telah pun menjawat jawatan Shaykh alIslam di Aceh.

Naskhah Zad al-Muttaqin dimiliki oleh kebanyakan perpustakaan seperti perpustakaan Anwariya dan Khanqah Kazhomiyyah Qalandariya. Pada tahun 1989, seorang professor, Masud Anwar Alavi tenaga pengajar Jabatan Bahasa Arab di Aligharh Muslim University telah menerima arahan daripada guru beliau Maulana Hafiz Shah Mujtaba Haidar Khalandar Mudzidul Ali untuk menerjemahkan naskhah berkenaan ke bahasa Urdu berserta catatan pinggirnya. Arahan tersebut diikuti dan kerja penerjemahan pun dilaksanakan sehingga sempurna. Walaupun begitu disebabkan oleh kesibukan tugas, beliau tidak dapat menyemak semula catatan yang dibuat sedangkan proses cetakan telah pun bermula. Begitulah keadaan yang terjadi dengan cetakan tersebut mengandungi perkara yang tertinggal dan terlepas dari penelitian. Namun begitu, guru beliau sering mengingatkan supaya cetakan diulang dan edaran diperluaskan. Oleh itu, sebelum ulang cetak bermula beliau mengambil peluang untuk menyemak dan melakukan pembetulan sehingga usaha berkenaan dapat dilakukan oleh beliau dengan sempurna (Abdul Haqq 2009). Kitab Zad al-Muttaqin tidaklah diguna sepenuhnya tetapi terhad hanya kepada bahagian-bahagian tertentu yang mengandungi maklumat silsilah tarekat Shaykh Abdul Haqq Muhaddith Dehlawi guna membandingkan dengan silsilah yang terdapat pada naskhah Mir'at al-Muhaqqiqin. Perkara terpenting ialah, silsilah tarekat yang terdapat di dalam kitab Zad al-Muttaqin dijadikan sebagai silsilah utama dan sebarang perbezaan yang ditemui dengan silsilah yang terdapat dalam manuskrip Mir'at al-Muhaqqiqin akan ditunjukkan secara perbandingan. Walaupun begitu manuskrip Mir'at al-Muhaqqiqin tetap menjadi manuskrip landasan yang mencetuskan usaha pencerahan silsilah dan aliran tarekat Shaykh Shamsuddin al-Sumatera i.

\section{Perbandingan Silsilah Mir'at al-Muhaqqiqin dan Zad al-Muttaqin}

Perbandingan silsilah yang terdapat dalam manuskrip Zad al-Muttaqin fi Suluk Tariq al-Yaqin dengan manuskrip MS 3841 [B] dan Ms. Inv. 1490 dicatat pada nota bawah. Manuskrip Mir`at al-Muhaqqiqin MS 3841 [B] disebut sebagai naskhah A dan MS. Inv. 1490 disebut sebagai naskhah B. Naskhah asas adalah silsilah yang dicatat dalam manuskrip Zad al-Muttaqin, iaitu silsilah utama. Maka perbandingan silsilah ini adalah antara silsilah yang dicatat oleh Shaykh Abdul Haqq dengan silsilah yang dicatat oleh Shaykh Shamsuddin al-Sumatera`i dalam manuskrip masing-masing. Silsilah utama yang dicatat oleh Shaykh Abdul Haqq ini dikenalpasti sebagai silsilah tarekat Qadiriyyah. Fakta ini dapat ditemui pada bahagian kitab Zad al-Muttaqin yang menyatakan wasiat yang ditulis oleh Shaykh Ali bin Husamuddin al-Muttaqi. Hal ini demikian kerana wasiat berkenaan menyebut tentang aliran tarekat beliau. Di sebabkan nama Shaykh Ali Muttaqi terdapat pada silsilah Shaykh Abdul Haqq dan silsilah Shaykh Shamsuddin al-Sumatera'i, maka Shaykh Ali Muttaqi menjadi individu penting yang menyatukan silsilah antara kedua-dua naskhah Mir'at al-Muhaqqiqin dengan naskhah Zad al-Muttaqin. Wasiat Shaykh Ali Muttaqi nukilan (Abdul Haqq 2009) adalah seperti berikut:

Bismillahir Rahmanir Rahim. Selawat dan salam ke atas Sayyidina Muhammad, keluarganya dan sahabat-sahabatnya. Inilah wasiat yang ditulis oleh faqir Ilallah, Ali bin Husamuddin yang masyhur sebagai Muttaqi. Wasiat ini ditulis pada hari yang mana ianya merupakan hari untuk meninggalkan dunia ini menuju ke akhirat. Tatkala faqir masih kecil, ayahku (r.a.) menjadikan daku murid kepada Shaykh Bajan (q.s.) - Tarekat itu adalah ketinggian, kesucian, wajd dan hal - Apabila aku mencapai usia yang dapat membezakan antara benar dan salah, aku menjadikan dirinya (Shaykh Bajan) yang terpilih sebagai Shaykhku. 


\begin{abstract}
Aku senang kekal dengannya sebagai Shaykhku. Shaykh telah berkata: "Apabila seseorang kanak-kanak dijadikan murid kepada seorang Shaykh, maka setelah cukup umur (baligh) dia mempunyai pilihan untuk kekal sebagai murid Shaykhnya atau bersahabat dengan Shaykh yang lain yang menjadi pilihannya." Bertitik tolak daripada panduan tersebut aku kekal sebagai murid Shaykh yang telah dipilih oleh ayahku untukku. Setelah kewafatan ayahku dan Shaykhku radiyallahucanhuma (semoga Allah meredhai keduanya), aku memperolehi khirqah khalifah Chishtiyyah daripada anak Shaykhku, al-Shaykh Abdul Hakim bin al-Shaykh Bajan (q.s.). Sesudah itu aku merindui Shaykh yang dapat memimpin dan menunjukiku sepanjang peringkat tarekat yang tinggi dan tak menentu ini. Aku dengan itu mengalih perhatian ke Multan dan tinggal di bawah khidmat arifbillah Shaykh Husamuddin Muttaqi untuk beberapa lama. Setelah itu aku musafir ke Haramayn Sharifain (Mekah dan Madinah). Di sana aku memilih untuk bersahabat dengan arifbillah Shaykh Abu al-Hassan al-Bakri (q.s.). Daripada beliau aku memperolehi khirqah khalifah tarekat Qadiriyyah, Shadhiliyyah dan Madyaniyyah. Aku juga memperolehi ketiga-tiga khirqah ini daripada Shaykh Muhammad bin Muhammad al-Sakhawi (q.s.).
\end{abstract}

Pengenalpastian aliran tarekat Shaykh Ali Muttaqi akan menatijahkan pengenal pastian aliran tarekat rohani Shaykh Shamsuddin al-Sumatera i. Namun wasiat ini, sekalipun ia menerangkan mengenai guru dan aliran tarekat rohani Shaykh Ali Muttaqi ia masih tidak lengkap sebagai suatu silsilah tarekat yang sempurna. Wasiat ini hanya memberitahu mengenai pengurniaan khirqah tarekat Qadiriyyah, Shadhiliyyah, Madyaniyyah dan Chistiyyah kepada Shaykh Ali Muttaqi daripada guru beliau tanpa menyatakan jurai silsilah secara terperinci. Silsilah yang selengkapnya hanya dapat dirujuk pada bahagian 'khilafat namah' (Abdul Haqq 2009) di dalam kitab Zad al-Muttaqin. Silsilah tersebut adalah silsilah tarekat Qadiriyyah, oleh itu ia tidak menjelaskan secara terperinci rantaian silsilah bagi tarekat Shadhiliyyah dan Madyaniyyah. Cuma dapat dipastikan silsilah tersebut meliputi silsilah tarekat Shadhiliyyah dan Madyaniyyah melalui guru Shaykh Ali Muttaqi, iaitu Shaykh Muhammad bin Muhammad bin alSakhawi (w. 1533M) (Abdul Haqq 2009) dan Shaykh Abu al-Hassan al-Bakri (w. 1543M) (alSha'rani 1999) yang adalah khalifah ketiga-tiga tarekat tersebut.

Bagi silsilah tarekat Chishtiyyah pula, dapat dikesan susur galurnya yang bermula dengan Shaykh Bahauddin Bajan Chishti (1507M) iaitu guru Shaykh Ali Muttaqi yang mengurniakan ijazah khalifah tarekat kepada anak beliau Shaykh Abdul Hakim (w. 1584) (Saiyid Athar Abbas Rizvi 1992, Vol. 2) dan diijazahkan pula kepada Shaykh Ali Muttaqi. Hanya sekadar itu yang diberitahu oleh Shaykh Ali Muttaqi. Maka bagi melengkapkan jurai silsilah sehingga kepada Rasulullah (s.a.w.) disatukan silsilah tarekat Chishtiyyah Shaykh Ali Muttaqi sekadar yang diberitahu oleh beliau disambung dengan silsilah tarekat Chishtiyyah Shaykh Ahmad al-Qushashi yang terdapat di dalam kitab Simt al-Majid (al-Qushashi 1909).

Bukti bertulis lain yang dapat mengukuhkan lagi aliran silsilah tarekat berkenaan ialah tatacara zikir yang ditunjukkan oleh Shaykh Shamsuddin al-Sumatera i, iaitu dengan menyebut kalimah La ilaha illallah dinaikkan lafaz Lailaha tersebut daripada bawah pusat dan disudahi dengan paluan sebutan kalimah illallah ke dada sehingga berbekas zikir tadi keseluruh anggota tubuhnya dan menjadi tetap zikir tersebut kepada orang yang berzikir. Kata Shaykh Shamsuddin di dalam Haqq al-Yaqin fi Aqidah al-Muhaqqiqin (MS 2581 F): "Maka seyogianya yang mengerjakan pekerjaan itu dengan diterbitkannya pada citanya kalimah La ilaha illallah itu di bawah pusatnya dan dipalukannya dengan cita kalimah illallah itu ke atas dadanya hingga berhubunglah bekas zikir itu dengan segala anggotanya dan tetaplah ia dalamnya". Sementara itu kaedah Shaykh Abu al-Hassan al-Shadhili mursyid tarekat Shadhiliyyah juga mempunyai 
persamaan dengan kaedah yang ditunjukkan oleh Shaykh Shamsuddin al-Sumatera i. Di mana kata Shaykh Abu al-Hassan al-Shadhili dinukil oleh Ibn `Ata’ Allah al-Iskandari (1381):

Setelah itu hendaklah penzikir melafaz La ilaha illallah dengan penuh kekuatan disertai pengagungan. Dia menaikkan kalimah berkenaan dari atas pusat. Lalu dengan lafaz Lailaha hendaknya ia berniat melenyapkan segala sesuatu selain daripada Allah dari kalbunya. Dan dengan lafaz illallah hendaknya ia berniat menanamkan lafaz berkenaan ke dalam kalbu (bertempat di dada sebelah bawah susu kiri) untuk kemudiannya diteruskan ke semua anggota tubuh sambil terus menerus meresapi maknanya.

Kaedah ini juga bersamaan dengan salah satu daripada beberapa kaedah zikir yang ditunjukkan oleh Shaykh Ahmad al-Qushashi (1909), mursyid tarekat Shattariyyah, Qadiriyyah, Shadhiliyyah, Chistiyyah, Ahmadiyyah Badawiyyah, Ahmadiyyah Shinawiyyah, Junaidiyyah, Rifaiiyyah, Hatimiyyah, Akhbariyyah, Hamadaniyyah, Junaidiyyah, Uwaisiyyah, Ghawtsiyyah, Suhrawardiyyah, Kubrawiyyah, Tayfuriyyah dan banyak lagi iaitu:

Dia harus menaikan La ilaha illallah dari atas pusat dengan berniat Lailaha menafikan selain Allah daripada hati dengan meniatkan illallah itu disampaikan kepada hati sanubari (bertempat di dada sebelah bawah susu kiri) supaya illallah itu tersemat di hati. Dengan itu ia memberinya (hati) ketetapan ketika ithbat (tiada Tuhan melainkan Allah). Ia akan menjalar di seluruh anggotanya. Antaranya (adab) juga menghadirkan makna zikir dengan hati pada setiap kali zikir. Tingkatan zikir yang paling rendah ialah setiap kali mengucap La ilaha illallah di dalam hatinya ia akan menafikannya dari hatinya. Apabila ia tidak menoleh kepadanya ketika berzikir bermakna ia telah menafikan segala-galanya dari hatinya dan diisikan tempat itu dengan Allah sahaja.

\section{Silsilah Tarekat Qadiriyyah}

Berdasarkan analisis yang telah dibuat, berikut ialah silsilah tarekat Qadiriyyah Shaykh Shamsuddin al-Sumatera i:

1. Al-Shaykh Shamsuddin ibn Abdullah al-Sumatera'i (w. 1630M).

2. Al-Shaykh Muhammad ibn Husin Jani Jamilah al-Bahmani.

3. Al-Shaykh Abdul Wahhab al-Muttaqi (w. 1606M).

4. Al-Shaykh al-Arifbillah Ali bin Husamuddin al-Muttaqi (w. 1567M). (Zad al-Muttaqin hanya menyatakan silsilah bermula dari Shaykh Ali Muttaqi sahaja).

5. Al-Shaykh Muhammad bin Muhammad bin Muhammad bin al-Sakhawi (w. 1533M).

6. Al-Shaykh Tahir bin Rabbani al-Zawawi.

7. Al-Shaykh Ahmad bin Musa al-Bashihi.

8. Al-Shaykh Shihabuddin Ahmad Arif Marzuq.

9. Al-Shaykh Ahmad Bashihi al-Mazkur.

10. Al-Shaykh Abi al-Hasan Ali al-Bashihi.

11. Al-Shaykh Abu al-Hasan.

12. Al-Shaykh Abi Hafs Umar bin Ali.

13. Al-Shaykh al-Sayyid Majiddin Abi Muhammad Saleh al-Zawawi.

14. Al-Shaykh Muhammad bin Muhammad bin al-Mukhallis al-Tibi.

15. Al-Shaykh Ahmad bin Id Mazuhama. 
16. Al-Shaykh Sharifuddin bin al-Adli.

17. al-Shaykh Jamaluddin Abi Muhammad Yusuf bin Muhammad Nasr al-Ma'dani.

18. Al-Shaykh Abi Abdullah Muhammad bin Ibrahim bin Abdul Wahid bin Ali bin Surur al-Muqaddisi.

19. Al-Shaykh al-Qutub al-Rabbani wa al-Ghawth al-Samadani Ghawth al-Thaqalain Muhyiddin Abi Muhammad Abdul Qadir al-Jilani (w. 1166M).

20. Al-Shaykh Abi Said al-Mubarak bin Ali al-Makhzumi (w. 1119M).

21. Al-Shaykh Abi al-Hasan Ali bin Muhammad bin Yusuf al-Hakari (w. 1093M).

22. Al-Shaykh Abi al-Farj Abd al-Rahman bin Abdullah al-Tartushi (w. 1055M).

23. Al-Shaykh Abdul Wahid (w. 1033M).

24. Al-Shaykh Abdul Aziz al-Timi.

25. Al-Shaykh Abi al-Qasim al-Junayd bin Muhammad al-Zujaji al-Qawariri al-Baghdadi (w. 910M).

26. Al-Imam Ali al-Ridha (w. 818M).

27. Al-Imam Musa al-Kazim (w. 799M).

28. Al-Imam Jaafar al-Siddiq (w. 765M).

29. Al-Imam Muhammad al-Baqir (w. 733M).

30. Al-Imam Zainal Abidin Ali bin al-Hussin (w. 712M).

31. Al-Imam Hussain bin Ali (w. 680 M).

32. Amir al-Mukminin wa Imam al-Muslimin Ali bin Abi Talib (r.a.) (w 661M).

33. Sayyid al-Mursalin wa Imam Aimmat al-Muttaqin wa Khatam al-Nabiyyin Muhammad Rasulullah (s.a.w.) (w. 632M).

\section{Silsilah Tarekat Shadhiliyyah}

Silsilah tarekat Shadhiliyyah Shaykh Shamsuddin al-Sumatera i yang melalui Shaykh Abu alHasan al-Bakri adalah seperti berikut:

1. Al-Shaykh Shamsuddin ibn Abdullah al-Sumatera'i.

2. Al-Shaykh Muhammad.

3. Al-Shaykh Abd al-Wahhab al-Muttaqi.

4. Al-Shaykh al-Arifbillah Ali bin Husamuddin al-Muttaqi.

5. Al-Shaykh Abu al-Hasan al-Bakri (w. 1543M).

6. Al-Shaykh Ahmad Zarruq (w. 1494M).

7. Al-Shaykh Shihabuddin Ahmad bin Abdul Qadir bin Muhammad bin Umar bin Uqbah al-Hadrami (w. 1421-89M).

8. Al-Shaykh Yahya bin al-Wafa' al-Qadiri (w. 1453M).

9. Al-Shaykh Ali bin Muhammad bin Wafa' al-Qurashi (w. 1310/11M).

10. Al-Shaykh Muhammad Wafa' Bahr al-Safa (w. 1364M).

11. Al-Shaykh Dawud al-Bakhili (w. 1332M).

12. Al-Shaykh Ahmad ibn Ata' Illah al-Iskandari (w. 1309M).

13. Al-Shaykh Abu al-Abbas al-Mursi (w. 1287M).

14. Al-Shaykh Abi al-Hasan al-Shadhili (w. 1258M).

15. Al-Shaykh Abdul Salam ibn Mashish (w. 1228M).

16. Al-Shaykh Abdul Rahman al-Attar al-Zayyat.

17. Al-Shaykh al-Ghawth Abu Madyan (w. 1198M).

18. Al-Shaykh al-Qutub al-Rabbani wa al-Ghawth al-Samadani Ghawth al-Thaqalain Muhyiddin Abi Muhammad Abdul Qadir al-Jilani (w. 1166M).

19. Al-Shaykh Abi Said al-Mubarak bin Ali al-Makhzumi (w. 1119M). 
20. Al-Shaykh Abi al-Hasan Ali bin Muhammad bin Yusuf al-Hakari (w. 1093M).

21. Al-Shaykh Abi al-Farj Abd al-Rahman bin Abdullah al-Tartushi (w. 1055M).

22. Al-Shaykh Abu Farj Abdul Wahhab al-Tamimi.

23. Al-Shaykh Abu Bakr al-Shibli (w. 946M).

24. Al-Shaykh Abi al-Qasim al-Junayd bin Muhammad al-Zujaji al-Qawariri al-Baghdadi (w. 910M).

25. Al-Shaykh Sirr al-Saqati (w. 867M).

26. Al-Shaykh Maaruf al-Karkhi (w. 815M).

27. Al-Shaykh Dawud al-Ta'i (w. 777-782M).

28. Al-Shaykh Habib al-Ajami (w. 737M).

29. Al-Shaykh Abi Said al-Hassan bin Yasar al-Basri (w. 728M).

30. Al-Imam al-Murtada Ali bin Abi Talib (r.a.).

31. Sayyid al-Mursalin wa Imam A-immat al-Muttaqin wa Khatam al-Nabiyyin Muhammad Rasulullah (s.a.w.).

\section{Silsilah Tarekat Madyaniyyah}

Melalui Shaykh Abu Madyan terbentuknya tarekat Madyaniyyah yang dinisbahkan kepada nama pengasasnya. Silsilah ini tidak menempuh jurai melalui Shaykh Abdul Qadir al-Jilani mahupun jurai Shaykh Abu al-Hasan al-Shadhili. Oleh yang demikian sisilah ini tidak dapat dinisbahkan kepada tarekat Qadiriyyah sekalipun antara individu yang menjadi guru kepada Shaykh Abu Madyan adalah Shaykh Abdul Qadir al-Jilani. Begitu juga silsilah ini tidak dapat dinisbahkan kepada tarekat Shadhiliyyah sekalipun antara individu yang menjadi murid kepada murid Shaykh Abu Madyan, iaitu Shaykh Abdul Salam Mashih adalah Shaykh Abu al-Hasan al-Shadhili. Paparan silsilah tarekat Madyaniyyah Shaykh Shamsuddin al-Sumatera'i adalah melalui Shaykh Abu al-Hasan al-Bakri, ia adalah seperti berikut:

1. Al-Shaykh Shamsuddin ibn Abdullah al-Sumatera'i.

2. Al-Shaykh Muhammad.

3. Al-Shaykh Abd al-Wahhab al-Muttaqi.

4. Al-Shaykh al-Arifbillah Ali bin Husamuddin al-Muttaqi.

5. Al-Shaykh Abu al-Hasan al-Bakri (w. 1543M).

6. Al-Shaykh Ahmad Zarruq (w. 1494M).

7. Al-Shaykh Ahmad bin Abdul Qadir bin Muhammad al-Hadrami (w. 1421-89M).

8. Al-Shaykh Muhammad bin Umar bin Uqbah al-Hadrami (w. 1385M).

9. Al-Shaykh Ahmad ibn 'Ashir al-Ansari (w. 1362M).

10. Al-Shaykh Muhammad ibn Isa.

11. Al-Shaykh Abu Zakaria al-Hahi (w. penghujung kurun ke-13M).

12. Al-Shaykh Ahmad ibn Salih al-Magiri (w. 1262M).

13. Al-Shaykh Abdallah ibn Abu Muhammad Salih al-Magiri (w. 1253M).

14. Al-Shaykh Abu Muhammad Salih ibn Yansaren al-Magiri (w 1234M).

15. Al-Shaykh al-Ghawth Abu Madyan (w. 1198M).

16. Al-Shaykh Abi al-Hasan Ali bin Hirzihim (w. 1164M)

17. Al-Qadi Abi Bakr Muhammad bin Abdullah al-Arabi (w. 1148M).

18. Al-Imam Abu Hamid Muhammad bin Muhammad al-Ghazali (w. 1111M).

19. Al-Imam Abi al-Macali Abd al-Malik ibn Rukn al-Islam.

20. Al-Shaykh Abi Talib Muhammad ibn Atiyyah al-Makki.

21. Al-Shaykh Abi Uthman Said bin Salam al-Maghribi (w. 983M). 
22. Al-Shaykh Abi al-Qasim al-Junayd bin Muhammad al-Zujaji al-Qawariri al-Baghdadi (w. 910M).

23. Al-Shaykh Sari al-Saqati (w. 867M).

24. Al-Shaykh Maaruf al-Karkhi (w. 815M).

25. Al-Shaykh Dawud al-Ta'i (w. 777-782M).

26. Al-Shaykh Habib al-Ajami (w. 737M).

27. Al-Shaykh Abi Said al-Hassan bin Yasar al-Basri (w. 728M).

28. Al-Imam al-Murtada Ali bin Abi Talib (r.a.).

29. Sayyid al-Mursalin wa Imam A-immat al-Muttaqin wa Khatam al-Nabiyyin Muhammad Rasulullah (s.a.w.).

\section{Silsilah Tarekat Chishtiyyah}

Paparan berikut merupakan silsilah terekat Chistiyyah Shaykh Shamsuddin al-Sumatera'i melalui jurai Shaykh Ali Muttaqi. Tarekat ini dinisbahkan kepada Chistiyyah melalui Shaykh Abu Ishaq al-Chisti. Berikut adalah silsilahnya:

1. Al-Shaykh Shamsuddin ibn Abdullah al-Sumatera'i.

2. Al-Shaykh Muhammad.

3. Al-Shaykh Abdul Wahhab al-Muttaqi.

4. Al-Shaykh al-Arifbillah Ali bin Husamuddin al-Muttaqi.

5. Al-Shaykh Abdul Hakim Shah Bajan (w. 1584M).

6. Al-Shaykh Bahauddin Shah Bajan Chishti (w. 1507M).

7. Al-Shaykh Burhanuddin Gharib (w. 1344M).

8. Al-Shaykh Nizamuddin al-Khalidi Al-Dahlawi (w. 1325M).

9. Al-Shaykh Fariduddin Mascud (w. 1265M).

10. Al-Shaykh Qutubuddin Bakhtiar Kaki (w. 1235M).

11. Al-Shaykh Yusuf Muhammad al-Chishti (w. 1067M).

12. Al-Shaykh Muhammad bin Ahmad Abdul Chishti.

13. Al-Shaykh Ahmad al-Chishti (w. 966M).

14. Al-Shaykh Abi Ishaq al-Chishti (w. 940M).

15. Al-Shaykh Uluw Mamshad al-Daynuri al-Alawi.

16. Al-Shaykh Abi Hubayrah al-Basri.

17. Al-Shaykh Huzayfah al-Mar'ashi (w. 822M).

18. Al-Shaykh al-Sultan Ibrahim bin Adham (w. 78 M).

19. Al-Shaykh Fadil bin Iyad (w. 803M).

20. Al-Shaykh Abdul Wahid bin Zayd (w. 793M).

21. Al-Shaykh Abi Said al-Hassan bin Yasar al-Basri (w. 728M).

22. Al-Imam al-Murtada Ali bin Abi Talib (r.a.) (w. 661M).

23. Sayyid al-Mursalin wa Imam A-immat al-Muttaqin wa Khatam al-Nabiyyin Muhammad Rasulullah (s.a.w.).

\section{Silsilah Tarekat Shattariyyah}

Perbincangan seterusnya dilanjutkan dengan mengambil kira pandangan dalam Mohd Nasrin (2008: 31), katanya: "Looking at the report on the Achehnese pilgrims meeting Shaykh Sibghat Allah (d. 1606) as mentioned in the Hikayat Acheh I am inclined to think that Shams al-Din had access to the Shattariyya order. This is due to the fact that Shaykh Sibghat Allah was a Shattari Shaykh". Peristiwa berkenaan merujuk kepada kepulangan Haji Ahmad dan Haji Abdullah ke 
Aceh setelah selesai menunaikan haji di Mekah. Mereka berdua sebaik sahaja sampai ke Aceh terus mengunjungi Shaykh Shamsuddin al-Sumatera`i bagi menyampaikan kisah bagaimana mereka ditanya oleh ulama di Madinah tentang negeri Aceh dan sultannya. Ulama yang berada di dalam majlis tersebut ialah Shaykh Sibghatullah, Shaykh Muhammad Mukarram dan Mir Jaafar, bersama-sama amir haji Bashah Yaman. Mir Jaafar kemudiannya datang ke Aceh dan mengunjungi Shaykh Shamsuddin lalu mengesahkan cerita dua orang haji tadi:

Maka menceritakan cerita ini dua orang celebi yang datang dari Aceh. Maka tatkala itu Shaykh Sibghatullahdan segala ulama yang dalam majlis itu sekaliannya memaca Fatihah akan Seri Sultan Johan Alam. Maka tatkala itu Mir Jaafar pun ada pada majlis itu. Setelah itu maka Haji Ahmad dan Haji Abdullah kembali ke Aceh Darul Salam. Apakala sampai ia ke Aceh Darul Salam maka datang ia kepada Shaykh Shamsuddin. Maka diceritakannyalah kepadanya . . . Setelah itu maka datang pula Mir Jaafar ke Aceh. Apakala ia datang ke Aceh maka datang ia kepada Shaykh Shamsuddin (Teuku Iskandar 2001).

Sekalipun peristiwa berkenaan menunjukkan adanya hubungan Shaykh Shamsuddin dengan Shaykh Sibghatullah selaku murshid tarekat Shattariyyah ketika itu. Mesti di ambil perhatian tentang tahun Shaykh Sibghatullah mengambil giliran selaku murshid tarekat Shattariyyah, iaitu pada tahun 1589 M selepas wafat gurunya Shaykh Wajihuddin (2012). Shaykh Sibghatullah pada tahun 1589 M mengajar di Bharauch dan hanya menunaikan haji di Mekah sekitar 1592/1593 M. Maka Shaykh Shamsuddin lebih berkemungkinan besar mempunyai hubungan dengan Shaykh Wajihuddin selaku murshid tarekat Shattariyyah pada waktu sebelum tahun 1589 Masihi, iaitu tahun sebelum wafat Shaykh Wajihuddin, berbanding berguru dengan Shaykh Sibghatullah. Tanpa menafikan adanya hubungan persahabatan murid dengan murid antara Shaykh Shamsuddin dengan Shaykh Sibghatullah.

Kemungkinan lain ialah Shaykh Shamsuddin menerima tarekat Shattariyyah melalui Shaykh Mir Jaafar yang datang ke Aceh seperti yang dijelaskan diawal tadi. Mir Sayyid Jaafar adalah murid kepada Shaykh Muhammad Rashid (Jawnpur), yang menjadi murid kepada Shaykh Abdullah Shattari (Agra), yang menjadi murid kepada Shaykh Muhammad Ghawth. Shaykh Muhammad Ghawth adalah guru kepada Shaykh Wajihuddin Alawi iaitu guru kepada Shaykh Sibghatullah. Oleh itu Mir Sayyid Jaafar sebagaimana Shaykh Sibghatullah adalah pengamal tarekat Shattariyyah daripada guru utama Shaykh Sayyid Muhammad Ghawth Khatiruddin Gwalior (Qazi Moinuddin Ahmad 2012). Bukti bertulis lain ialah manuskrip Cod. Or. 7344 (Anon. t.th.) Perpustakaan Universiti Leiden yang mengandungi pengajaran zikir daripada Shaykh Shamsuddin yang sama dengan apa yang terdapat dalam kitab Jawahir alKhams (Muhammad 1971) khususnya pada perenggan kedua. Transliterasinya seperti berikut:

Bismillahirrahmanirrahim. Adapun inilah wiridnya Kiyai Shamsuddin sesudah zikir nafi dan ithbat. Maka iaitu zikir darab tiga belas namanya. Maka iaitu hendak menyebut La ialaha illallah sekali dan menyebut illallah itu tiga belas kali, sekurang-kurangnya menyebut nafi itu tiga kali dan menyebut ithbat itu tiga belas kali dan tiada hingganya di dalam membunyikan itu. Adapun yang dinafikan itu tatkala menyebut nafi itu bumi ketujuh serta isinya sekelian dan langit ketujuh serta isinya sekelian dan Arash, dan Kursi, dan Syurga dan Neraka dan Lawh dan Qalam dan tulang dan Anasir empat perkara. Tetapi tiada kamu ketahui itu sebanyak-banyaknya pertingkahi zikir itu sekelian. Maka tiada sempurna kamu mengamalkan dia melainkan dengan fatwa guru dan lagi tiada sempurna kamu mengamalkan dia melainkan dengan wasiatnya guru. Dan 
sesudahnya itu maka zikir ism dhat iaitu Allah, Allah sekuasanya. Dan sesudahnya itu maka zikir ism dhat dalam ghaib iaitu Allah Hu sekuasanya. Sesudahnya zikir ghaib di dalam zat iaitu Hu Allah sekuasanya. Dan sesudahnya itu zikir ism ghaib di dalam ghaib iaitu Hu, Hu sekuasanya. Tetapi tiada kamu ketahui daripada sekelian zikir itu melainkan dengan petunjuk guru dan lagi tiada sempurna kamu mengamalkan itu melainkan dengan wasiatnya guru, tetapi Allah juga yang menolongi.

Bermula zikir sirri beberapa warnanya maka setengah daripada zikir shughul (شغل) nafas namanya, maka iaitu hendak ditanjakan pada kalimah yang dahulu ketika mengeluarkan nafas. Hendak ditanjakan pada kalimat yang kedua ketika memasukkan nafas. Dan setengah daripada zikir shughul qalbi namanya maka iaitu hendak jangan hatinya orang itu sempurna dan pisahnya maka setengah daripada zikir shughul hal namanya hendak ditanjakan daripada kalimat yang dahulu ketika menekankan lututnya yang kanan hendak ditanjakan daripada kalimat yang kedua ketika menekankan lututnya yang kiri. Maka setengah daripada zikir shughul insan kamil iaitu hendak menyifatkan rupanya guru iaitu yang dibuat pehiasan itu [angan-angan] kepada Allah Taala. Maka iaitu zikir shughul ibarat iaitu hendak menyifatkan kepada ism-ism Allah sebanyakbanyaknya sebiji-sebiji. Dan setengah daripadanya maka iaitu zikir shughul mir'at iaitu hendak mengeluar di dalam kaca kerana hendak itu melihat di bayang-bayangnya sendiri. Itulah dibuat perhiasan angan-angan kepada Allah Taala dan setengah daripadanya maka iaitu zikir shughul astalah. Bermula zikir itu dua suatu astila 'Ishqiya dan kedua astila Naqshbandiyyah.

\section{Pemetaan Silsilah Tarekat Shaykh Shams al-Din al-Sumatra'i}

Shaykh Shamsuddin al-Sumatera`i adalah pembesar tertinggi Kerajaan Aceh Darussalam yang menjawat jawatan Shaykh al-Islam selama tiga era Sultan berturut-turut, iaitu Sultan Alauddin Riayat Syah al-Mukammil (1585-1604 Masihi) Sultan Ali Riayat Syah (1604-1607 Masihi), Sultan Iskandar Muda Meukuta Alam (1607-1636 Masihi) (Mohammad Said 1981; Nieman 1907; Lombard 1986). Dalam masa yang cukup panjang ini telah memberi gambaran bahawa Shaykh Shamsuddin adalah tokoh ulama yang mempunyai pelbagai disiplin ilmu yang bervariasi lagi mendalam dan memiliki keperibadian utuh melebihi ulama-ulama Aceh lain ketika itu. Beliau bukan hanya berperanan sebagai tokoh agama, malah penasihat sultan, diplomat dan jurubicara Kerajaan Aceh Darussalam sekaligus berperanan sebagai mursyid tarekat rohani kepada Baginda Sultan sendiri dan seluruh rakyat jelata.

Ketokohan Shaykh Shamsuddin sebagai tokoh ulama rasmi Kerajaan Aceh Darussalam telah dibendung oleh fatwa sesat, zinddiq dan kafir oleh agenda politik Shaykh Nuruddin alRaniry untuk meraih kepentingan menyebabkan hampir semua karya Shaykh Shamsuddin di hadapan masjid Bait al-Rahman, Banda Aceh. Namun demikian, beberapa hasil karya Shaykh Shamsuddin yang masih dapat ditemui sehingga kini sekalipun berlaku peristiwa pemusnahan ke atas karya-karya beliau, cukup membuktikan bahawa beliau adalah seorang ulama yang aktif menulis, sebagaimana diperakui oleh Shaykh Nuruddin sendiri dalam Bustan al-Salatin (Teuku Iskandar 1966). Dan ini juga agenda orientalis Barat dewasa ini seperti R.A. Nicholson, Massingon dan lain-lain (al-Attas 1963) yang berusaha untuk memadam kehebatan ketokohan Shaykh Shamsuddin sebagai Shaykh al-Islam, ulama rasmi Kerajaan Aceh Darussalam dengan tuduhan pengaruh Syiah Isma'iliyyah. Ini memberi impak negatif yang mendalam terhadap masyarakat Alam Melayu hari ini. Dengan penemuan sumber manuskrip yang tersisa dapat 
menelusuri silsilah tarekat rohani dan silsilah ilmu Shaykh Shamsuddin al-Sumatera i melalui karya-karya beliau yang masih berbentuk tulisan, iaitu manuskrip Mir'at al-Muhaqqiqin. Ini adalah sumbangan terhadap pencerahan yang lebih terhadap ijazah pertalian kerohanian tokoh ulama ini. Perkara ini diharapkan dapat bertindak selaku asas kepada pengkajian lanjutan, sumbangan yang mengisi lompang pengkajian terdahulu. Berikut ialah pemetaan silsilah bagi tarekat rohani Shavkh Shams al-Din al-Sumatra'i:

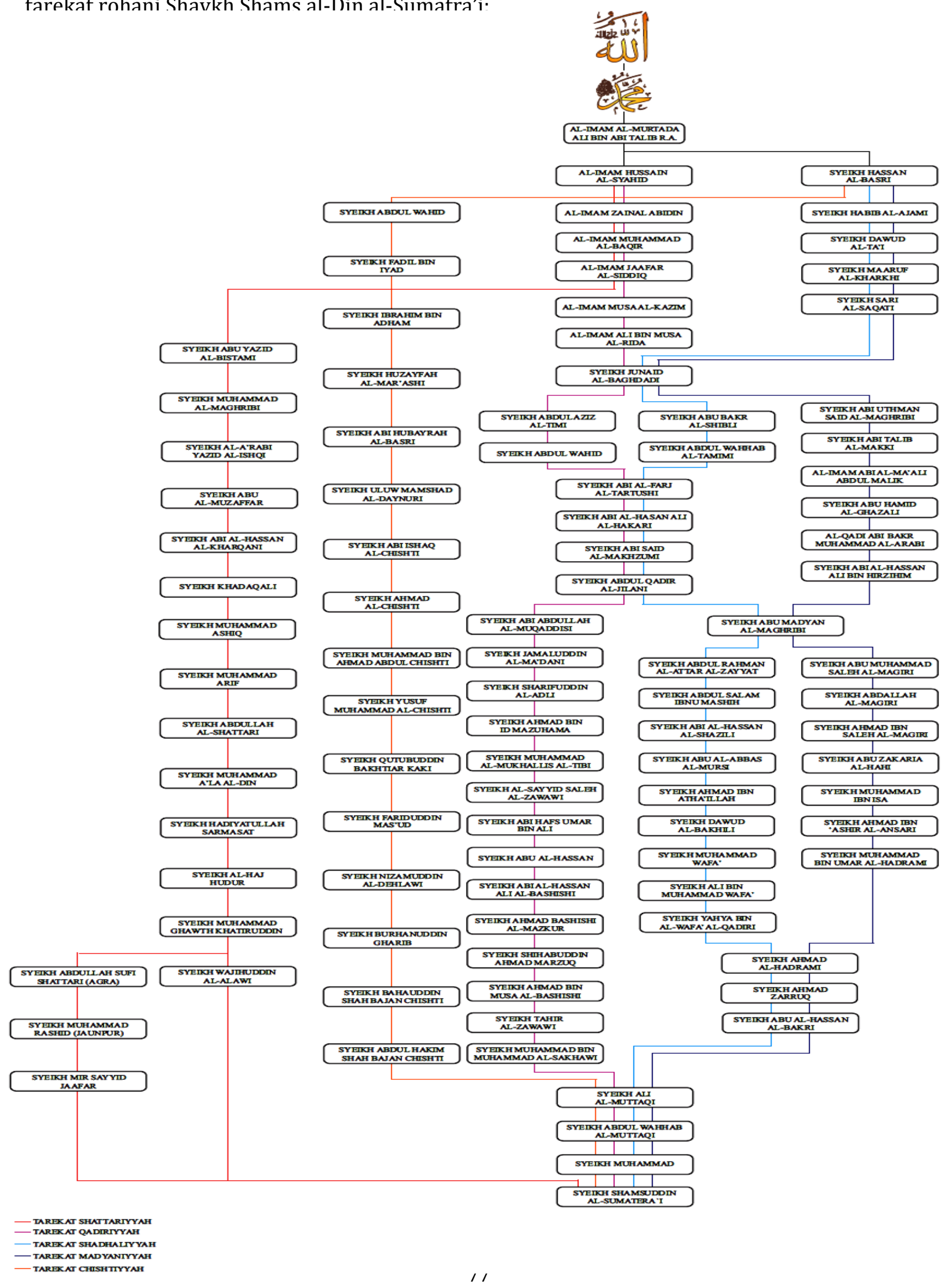




\section{References}

Abd al-Halim Mahmud. 1119H. Lata if al-Minan li Ibn `Ata Allah al-Sakandari. Cairo: Dar alMa'arif.

Abdul Haqq Muhaddith Dehlawi. 2009. Zad al-Muttaqin fi Suluk Tariq al-Yaqin. Aligarh: U.P. Aligarh Muslim University.

'Abd al-Qadir 'Isa. 2001. Haqa'iq 'an al-Tasawuf. Halab: Dar al-'Irfan.

Ahmad Daudy. 1978. Syeikh Nuruddin ar-Raniry Sejarah, Karya dan Sanggahan terhadap Wujudiyyah di Aceh. Jakarta: Penerbit Bulan Bintang.

Ahmad ibn Ibrahim ibn Ilan. 2011. Sharh al-Hikam al-Ghawthiyah Shaykh Abu Madyan alMaghribi. (Mengaji al-Hikam Jalan Kalbu Para Perindu Tuhan). Transl. Fauzi Bahreisy. Jakarta: Penerbit Zaman.

Anon. n.d. n.t. Cod. Or. 7344, Perpustakaan Universiti Leiden.

Drewes, G. W. J. \& Brakel, L. F. 1986. The Poems of Hamzah Fansuri. Belanda: Foris Publication.

al-Ghazali, Abi Hamid Muhammad. 1988. Al-Munqidh min al-Dalal. Beirut: Dar al-Kitab al'Ilmiah.

al-Iskandari, Ibn `Ata’ Allah. 1381. Miftah al-Falah wa Misbah al-Arwah. Cairo: Mustafa al-Babi al-Halabi wa Awladuh.

Johns, A. H. 1997. The Encyclopedia of Islam. Sunt. C.E. Bosworth et al. Jil. 9. Leiden: Brill.

Johns, A. H. 2009. Reflections on the Mysticism of Shams al-Din al-Samatrai. Dlm. Jan van der Putten \& Mary Kilcline Cody (pnyt.) Losts Times and Untold Tales from the Malay World. Singapura: National University of Singapore Press.

Johns, A. H. 2009. Essays in Arabic Literary Biography. Vol. 2. Wiesbaden, German: Harrassowitz Verlag.

Mohamad Nasrin. 2008. A Critical Edition and Study of Ḥaqq al-Yaqin fi Aqidat al-Muhaqqiqin of Shams al-Din Sumatra'i. Tesis ISTAC, IIUM.

Mohammad Said. 1981. Aceh Sepanjang Abad. Vol. I \& II. Medan: Waspada.

Mohd Syukri Yeoh Abdullah. 2011. Zawiyah dalam Lipatan Sejarah dan Kebudayaan Alam Melayu. Bangi: Institut Alam dan Tamadun Melayu (ATMA), UKM.

Muhammad bin Khatiruddin al-Ghawth. 1971. Jawahir al-Khams. Beirut: Dar al-Kutub alIlmiyyah.

Nieman, G.K. (pnyt.). 1907. Bloemlezing uit Maleische geschriften. Twede Stuk: Martinus Nijhoff's Gravenhage.

Nuruddin al-Raniri. 1955. Tibyan fi Ma'rifat al-Adyan. Salinan manuskrip dalam P. Voorhoeve. Twee Maleise Geschriften Van Nuruddin Ar-Raniri In Facsimile Uitgegeven Met Aantekeningen. Leiden: E. J. Brill.

Nuruddin al-Raniri. Ma'ul Hayati li Ahl al-Mamat. MS 547, Perpustakaan Negara Malaysia.

Lombard, Denys.1986. Kerajaan Aceh Jaman Sultan Iskandar Muda. Jakarta: Balai Pustaka.

Qazi Moinuddin Ahmad. 2012. History of the Shattari Silsilah. New Delhi: Idarah-i Adabiyat-i Delli.

Al-Qushashi, Safiuddin Ahmad bin Muhammad bin Abdul Nabi. 1909. Al-Simt al-Majid Fi Sha'n Wa al-Zikr Wa Talqinih Wa Salasil Ahl al-Tawhid. Hyderabad: Matba'ah Majlis al-Da'irah al-Ma'arif al-Nizamiyyah.

Saiyid Athar Abbas Rizvi. 1997. A History of Sufism In India. Jil. 1. New Delhi: Munshiram Manoharlal.

Saiyid Athar Abbas Rizvi. 1992. A History of Sufism In India. Jil. 2. New Delhi: Munshiram Manoharlal.

Sangidu. 2008. Wachdatul Wujud: Polemik Pemikiran Sufistik antara Hamzah Fansuri dan Shamsuddin as-Samatrani dengan Nuruddin ar-Raniri. Yogyakarta: Gama Media. 
Shaykh Abdul Rauf. Umdat al-Muhtajin ila Suluk Maslak al-Mufridin. MS1314, C, Perpustakaan Negara Malaysia.

Shamsuddin al-Sumatera i. Haqq al-Yaqin fi Aqidat al-Muhaqqiqin. MS 2581 F, Perpustakaan Negara Malaysia.

Shamsuddin al-Sumatera'i. Mir'at al-Muhaqqiqin. MS 3841 (B), Perpustakaan Negara Malaysia. al-Sha'rani, Abdul Wahhab bin Ahmad bin Ali. 1999. Al-Tabaqat al-Sughra. Beirut: Dar al-Kutub al-'Ilmiyah.

Syed Muhammad Naguib al-Attas. 1963. Some aspects of Sufism as understood and practised among the Malays. Singapore: MSRI Ltd.

Teuku Iskandar. 2001. Hikayat Aceh. Kuala Lumpur: Yayasan Karyawan.

Teuku Iskandar. 1966. Nuru'd-din ar-Raniri: Bustanu's-Salatin bab II, fasal 13. Kuala Lumpur: Dewan Bahasa dan Pustaka. 